\title{
Gendered Market Subjectivity: Autonomy, Privilege, and Emotional Subjectivity in Normalizing Post-socialist Neoliberal Ideology
}

\author{
Katherine Sredl \\ Loyola University Chicago, ksredl@luc.edu
}

Follow this and additional works at: https://ecommons.luc.edu/business_facpubs

Part of the Eastern European Studies Commons, and the International Business Commons

\section{Author Manuscript}

This is a pre-publication author manuscript of the final, published article.

\section{Recommended Citation}

Sredl, Katherine. Gendered Market Subjectivity: Autonomy, Privilege, and Emotional Subjectivity in Normalizing Post-socialist Neoliberal Ideology. Consumption Markets \& Culture, 21, 6: 532-553, 2018. Retrieved from Loyola eCommons, School of Business: Faculty Publications and Other Works, http://dx.doi.org/10.1080/10253866.2017.1374950

This Article is brought to you for free and open access by the Faculty Publications and Other Works by Department at Loyola eCommons. It has been accepted for inclusion in School of Business: Faculty Publications and Other Works by an authorized administrator of Loyola eCommons. For more information, please contact ecommons@luc.edu.

\section{(c) $($ () $\ominus$}

This work is licensed under a Creative Commons Attribution-Noncommercial-No Derivative Works 3.0 License. (C) Taylor \& Francis Group, 2017 


\title{
Gendered market subjectivity: autonomy, privilege, and emotional subjectivity in normalizing post-socialist neoliberal ideology
}

\author{
Katherine C. Sredl \\ Department of Marketing, Quinlan School of Business Administration, Loyola University \\ Chicago, Chicago, IL, USA \\ ksredl@ luc.edu Loyola University Chicago, 16 East Pearson St, Chicago, IL, 60611 USA
}

\begin{abstract}
:
Most prior studies of marketplace ideology foreground consumer agency as identity co-creation or opposition to ideology. In this research, I consider how the logics of the dwindling state and global neoliberalism discursively form consent in post-socialist Zagreb, Croatia. I use recollections and small group discussions to compare women's class and generationally based experiences of the daily family meal and work, during Yugoslav exceptionalism and privatization. Changing social relations normalize the gendered subjectivity of neoliberalism in post-socialist Zagreb, characterized by autonomy, the privilege of the younger generation, and the emotional subjectivity of anxiety and loss. Linking consumer experiences to the changing role of the state and market ideologies contributes to scholarship on globalization, gender, the socio-historic patterning of consumption, and marketplace ideology, by demonstrating that changes in ideology and state disrupt and replicate privilege to create new, gendered market subjectivities and social inequalities, normalized through changing everyday social relations.
\end{abstract}

\section{Keywords:}

Croatia; gender; globalization; governmentality; consumption in post-socialist societies; intersectionality 


\section{Gendered Market Subjectivity}

\section{Introduction}

Prior research on market ideology has tended to explore how consumers use marketplace ideology to co-create identities offered by the market, how ideology constrains active identity cocreation, how consumers oppose ideology through parody and other forms of play, and how identity might be a means of challenging marketplace ideologies (Arnould and Thompson 2005; Holt 2002; Izberk-Bilgin 2012; Mikkonen and Bajde 2012; Thompson and Haytko 1997). Theories of governmentality, discursive power, and performativity have been applied to understanding the relationship between ideology, gender, and everyday consumption (Butler 1993; Foucault 1991; Mikkonen, Vicdan, and Markkula 2014). For example, men may use class to customize discourses of gender ideology in the marketplace, further demonstrating the ways that everyday consumption serves as a gendered, socializing force (Holt and Thompson 2004). Zayer et al. (2012) demonstrate that gendered market ideology bounds performances of gender into specific norms. Focusing on questions of agency, these prior works approach consumption as active and as supporting, challenging, or transforming dominant ideologies of the market.

Researchers have extended the marketplace ideology scholarship by theorizing the ways that the logics and morals implicit in market ideologies and related political-economic structures influence consumer subjectivity and become normalized in fields of action (Borgerson 2005; Dean 1999; Giesler and Veresiu 2014). Their work often takes the form of historical or longitudinal studies, and has explored such questions as the formation of the responsibilized consumer in the neoliberal era or the formation of the active consumer in the sixteenth century 
Ottoman Empire (Giesler and Veresiu 2014; Karababa and Ger 2011). These scholars have also called for research that links consumer phenomenon with ideology and structure (Askegaard and Linnet 2011; Giesler and Veresiu 2014; Karababa and Ger 2011). Answering that call, this research extends theory on market ideology by linking gendered consumer experiences of social relations with the logics of the changing market ideology and the political and economic structures in which they are situated. It analyses changes in everyday social relations as a means through which consent for new ideologies and state logics - specifically, neoliberalism - is discursively created and new subjectivities are established.

In the context of this research, the dislocation of marketplace ideology and the role of the state in daily life in post-socialist Croatia in the 1990s and 2000s, women are in the process of becoming subjects of globalizing neoliberalism, with its logic of the middle-class, selfmonitoring, consuming woman, autonomy and flexible work arrangements, and the normalization of market logics in daily life (Scharff 2014). Depending on their age at the time of privatization, women's experiences of becoming neoliberal subjects in Croatia are informed in different ways by their subjective experiences with Yugoslav exceptionalism, the market ideology of Yugoslavia, and its focus on gender and class equality, labor, and geo-political independence; I explore these experiences of the old system through retrospective interviews (Otnes et al. 2006; Sredl 2007). The tension between Yugoslav exceptionalism and neoliberal gendered ideologies surrounding the self, changing social relations, and the diminished role of the state in the new order, offers and important context for understanding the relationship between the state, marketplace ideology, and gendered consumer subjectivity. 
The data in this article come from my research with female informants who were purposively selected to represent three class and generational positions in Zagreb, Croatia. The generations are: Gen I, women who came of age in the Golden Era of Yugoslav socialism, Gen II, women who came of age in its decline, and Gen III, women who came of age during privatization. The informants are also categorized by their social class: working, middle, and upper middle class. By making comparisons between experiences of privilege, in the form of class and generation, I offer insights into the dislocations and consistencies of subjectivity and social relations in the changing marketplace ideology of post-socialist Zagreb, Croatia.

Power worked discursively in everyday life in socialist Yugoslavia (Luthar and Pušnik 2010). Thus, my retrospective interviews focus on two quintessential, everyday experiences of women in the old and new regimes: participation in the labor market and everyday consumption surrounding the daily family meal (lunch). Gendered labor, especially in factories, had an ideological element in Yugoslavia as part of the process of modernizing society and building socialism. Prior research on women's experiences of transformation in the GDR and in Poland demonstrates that factory work was also place for social life under socialism (Berdahl 1999; Dunn 1999). In contrast, global neoliberal ideology conceptualizes the female worker as a consumer, an individual, in a state of perpetual self-transformation, as entrepreneurial, and as middle class; work in the neoliberal ideological framework is implied to mean self-actualization (Scharff 2014).

The gendered, every day, domestic sphere, and the sphere of work for working, middleclass, and upper-middle-class women of three different generations, have largely tended to be overlooked in many prior studies of the discursive power of ideology in studies of socialism and 
its transformation (Luthar and Pušnik 2010, 4). Instead, the research emphasis is on public spectacle, such as sporting events, or shopping, usually framed as lack of goods (Luthar and Pušnik 2010). In consumer research, domestic consumption of meals and women's participation in the workforce are usually understood as variables that influence family consumption, and overlooked as a site for understanding the discursive power of gendered, marketplace ideology, with few exceptions (Zayer et al. 2012). In this research, I frame the family daily meal (lunch) and women's work as sites for exploring the discursive power of marketplace ideologies of gender in Zagreb, past and present. I use informant reflection on the continuities and disruptions of what Luthar and Pušnik $(2010,2)$ call "the everyday and the ordinary," of work and socializing, to shed light on the ways that marketplace ideology works create new hierarchies.

The Findings point to themes of Autonomy, The Privilege of Generation, and Emotional Subjectivity. In the first theme, we see changes to the family meal as an example of the normalization of Autonomy. In the past, because most families were similarly engaged in the daily family meal at $4 \mathrm{pm}$, it could be seen as a discursive exercise in social cohesion across families of slightly more and less privilege. Preparing the meal and similar family care was also part of women's burden of workplace, domesticity, and childcare (Leinert Novosel 1990). Now, the dinner table signifies individual autonomy and class difference. Financially privileged Mothers discursively practice the autonomy demanded by neoliberalism by choosing individual activities for their children, and by implication managing their own work hours. The culturally shared experience of the table becomes one managed autonomously by each family that can afford the lessons and activities, according to the needs of each family member. The shift to individualizing afternoon children's activities into lessons as a means of normalizing the 
individualization of the new ideology potentially creates new inequalities between children of parents would can afford lessons, and by extension are better prepared for the labor market and its new demands on the individual, and those who cannot.

Section two of the Findings, The Privilege of Generation, examines the tension between Gen III University students and their Gen I Mothers over attending the daily family meal at home. Gen I women, like their Gen III daughters, are beneficiaries of gendered marketplace ideology in the form of University education and jobs in the professions. Women's education and employment were part of the Yugoslav exceptionalism notion of equality (Sredl 2009). The ideal neoliberal woman, generally speaking, is a young woman who is autonomous, independent, and sees herself as the beneficiary of labor market gender equality (Scharff 2012). Being the beneficiary of labor market gender equality puts responsibility for succeeding in a very risky market on Gen III women, starting with University study, while the old ideology put responsibility on the state. In turn, Gen III women must internalize the risks that come with their privilege and act in ways that minimize risk, and disrupt social relations, such as deciding to stay at the University and study and eat with peers, rather than going home to their Gen I mothers for meals. Social relations surrounding meals change, marginalizing Gen I Mothers, many of whom took early retirement or are later in their careers. Rather than seeing Gen I women, who miss the daily meal, as failing to adapt to the new ideology, I suggest that the new ideology, with its emphasis on the ideal woman as young, autonomous, and self-actualizing in an equal but uncertain labor market, has no room for their age and career stage. The decline of the meal normalizes the privilege of being young, along with self-actualization through professional work. 
As in the first two themes of the Findings, continuity and disruption continue in the third theme, Emotional Subjectivity. While formerly working-class women are now unemployed, and women working in the professions remain privileged, they have both lost the security of the old system and its ideology as better than West and East. Globalizing neoliberalism leaves them both feeling shame and lost pride, and anxiety about their employment. I consider this sense of anxiety, uncertainty, and lost pride to be an emotional subjectivity. This emotional subjectivity of global neoliberalism in Croatia tends to result in much less socialization than in the past; less socialization becomes a means of discursively normalizing the new emotional subjectivity and the uncertain labor market of neoliberal globalization and the dwindling role of the state in Croatia.

These findings have implications for scholars of globalization, who are interested in the ways that the globalization of neoliberal ideology reproduces, challenges, and normalizes social privileges, scholars of the socio-historic patterning of consumption, who look at a breadth of contexts in their exploration of the ways that consent for governance is discursively created through normalizing processes such as gendered everyday social relations, and scholars of gendered marketplace ideology, who are interested in the ways that the complementary logics of the state and marketplace ideology direct gendered market subjectivities and the structures and social relations in which inequities and logics are discursively normalized.

\section{Theoretical Foundations}

Market Ideology and Discursive Power in Yugoslavia 
Yugoslavia was not behind the Iron Curtain; as such, Yugoslav socialism was distinct from Soviet socialism and the socialism of the Warsaw Pact countries. Yugoslav consumer culture tended to justify the unique geo-political situation of Yugoslavia, a non-aligned state; Yugoslavia seemed liberal, compared to state policies of the Warsaw pact countries (Sredl 2007). Perhaps because of notions of ideological power as working from the top-down, especially in states with authoritarian, one-party rule, most research on ideology and power in this region focuses on institutions and ideology. The works can have an implicit assumption that life under totalitarianism was one of official and unofficial selfhood (Luthar and Pušnik 2010).

However, scholars of socialism in Yugoslavia, such as Luthar and Pušnik (2010), argue that power in socialist states worked as "a matter of joint consent and coercion," especially in the realms of everyday life, domesticity, labor, and habitual social practice (10). Luthar and Pušnik (2010) consider these everyday spaces important for researching power because they are at the "margins ... where it [power] becomes dispersed throughout social institutions and practices" (11). They argue that, in the everyday of domesticity of Yugoslavia, for example, power functions "at the level of subjectivity" (11). The state and its ideology created consent (and dissent) in the Yugoslav era, not, generally speaking, by force (although the state also used force or the threat of force) but in a discursive manner: by regulating everyday culture, and by the everyday practices of everyday citizens who internalized the social subjectivities created by the system through their mundane, everyday activities (Luthar and Pušnik 2010).

In Yugoslavia, the state's gender ideology brought massive improvements in women's literacy, education, and participation in politics, industrial labor, and the professions, as part of the modernization project of Yugoslav socialism (Sredl 2009; Sredl and Renko 2009). Official 
feminism before 1953 focused on women's fighting "alongside men" during the Partizan (communist and anti-Axis, anti-fascist) movement during World War II guerilla fighting. The ideology was positioned against Western feminism, which was critiqued in official discourse as individualistic, bourgeois, and morally and politically wrong. As the economy grew and the state opened its borders, the gendered aspects of Yugoslav exceptionalism, as evidenced in consumer culture, meant the opening of self-service grocery stores and other consumption and household conveniences (Patterson 2011; Sredl 2007).

Like Luthar and Pušnik (2010), I approach ideology in the context of socialism as operating discursively through the everyday, specifically, work and the daily family meal. Furthermore, I suggest that the power of ideology functions in a discursive manner after socialist Yugoslavia (1945-1991) as well. My perspective is influenced by not only Luthar and Pušnik (2010), Berdahl (1999), and Verdery (1996), but also by prior consumer research on market ideology in the US and other Western European contexts.

\section{Consumer Research on Market Ideology}

Questions of how consumers use marketplace ideology to co-create identities offered by marketplace ideology, or how ideology constrains active identity co-creation, tends to dominate consumer behavior research on marketplace ideology (Arnould and Thompson 2005). Thompson and Haytko (1997) suggest, through their interpretive research with individual consumers in the US, that consumers actively use marketplace fashion ideology to oppose and to reflect on identity and to understand abstract ideas such as gender relations and social group dynamics. Holt (2002), addressing the question of marketplace ideology and agency, explores individual 
consumers who create identity through experiences of nonconformity on the socio-economic margins of the US to argue that consumers are not passive, and that brands (and brand managers) assume an active consumer who, along with marketers, is constantly co-creating the market. Holt and Thompson (2004) use discourse analysis of ideological tropes of masculine identity, and analysis of individual white, middle-aged, working and upper-middle-class men and their identity projects in the US, to argue that social structures are a frame of reference from which ideological tropes of masculine identities are refined through everyday consumption.

Mikkonen and Bajde (2012) expand the question of marketplace ideology, consumption, and identity as a form of agency, by looking at parody of ideology as a form of consumption of ideology. They use literary theory and discourse analysis of the Festivus celebration on Seinfeld, the hit US television show, and individual YouTube videos of Festivus celebrations, to demonstrate that parody consumption challenges dominant discourses and conventions of consumption and holiday and creates an emancipatory space for the consumers participating in parody. Furthering research that complicates the notion that identities offered by discourses of ideology are liberating, Zayer et al. (2012) demonstrate that gendered market ideology, based on their analysis of the shows Sex and the City and Entourage, bounds performances of gender fluidity.

Izberk-Bilgin (2012) looks at oppositional ideology and suggests that oppositional marketplace ideology tends to govern the consumer choices of members of groups, such as lower-income Turkish consumers who reject global brands. In another exploration of oppositional marketplace ideology, Mikkonen, Vicdan, and Markkula (2014) use theories of governmentality to analyze the discourses of fashion in the hit BBC show, What Not to Wear. 
They demonstrate that the discourse of consumption surrounding the oppositional marketplace ideology of wardrobe self-help normalizes oppositional marketplace consumption, thereby limiting its emancipatory power. In looking at oppositional ideology, Izberk-Bilgin (2012) and Mikkonen, Vicdan, and Markkula (2014) seem to further the argument that the marketplace tends to allow agency through opposition or choice, thereby normalizing opposition.

Üstüner and Holt (2010) explore Westnerization as organizing consumption of selfdescribed authentic Turkish identity or Western identity among women with lower and higher cultural capital in Turkey. The tension in identity and capital between the groups suggests local political tension (Thompson 2014). Yet the changing role of the state in the relations between these groups remains unexplored in the article's contributions. Likewise, Coulter, Price, and Feick (2003), in their study of the origins of product involvement and brand commitment in postsocialist central Europe (Hungary and Romania), focus on discourses and identity in their research. Indeed, political tensions are often part of globalization processes and expressed through group identity consumption (Sredl 2005). Still, the changing role of the state in market ideology and gendered subjectivity remains unexplored in post-socialist contexts, perhaps due to the focus on identity.

Although there may be differences in perspectives on the relationship between consumption and marketplace ideology as a somewhat creative or as a somewhat limiting form of agency, either through individual identity or through groups using oppositional ideologies, nevertheless, there tends to be an overall agreement in research on marketplace ideology that individual consumption operates to support or challenge dominant ideologies of the market, to greater and lesser extents. Extending this perspective, scholars have recently demonstrated that, 
by looking at the logics of marketplace ideologies and the logics of the specific socio-historic and political and economic structures in which they are situated, we may further understand how these arrangements direct consumer subjectivities, such as responsibilized or identity-seeking (Borgerson 2005; Giesler and Veresiu 2014). Such work, scholars argue, moves questions of the power of marketplace ideology beyond the duality of identity as more or less agentic to asking how consent for the logics of marketplace ideology and logics of the state is formed. For example, Giesler and Veresiu (2014), in their ethnography of the World Economic Forum and analysis of its publications, demonstrate that the dwindling role of the state and the normalization of the market in daily life, in an era of neoliberal mythology, direct consumers toward taking responsibility for the environment. Karababa and Ger (2011) demonstrate that the changing political relationship between the Sultan and the commercial sector was influential in forming the active consumer subject in sixteenth century Ottoman Turkey. Likewise, Aitken (2003) demonstrates that the ideology of financial literacy shifts the cause of successful or unsuccessful return on investment from the stock market to individual consumers.

Most of the research in this line of exploration of subjectivity and marketplace ideology is historical or longitudinal; scholars such as Giesler and Veresiu (2014) and Askegaard and Linnet (2011), among others, have called for research that connects consumer experiences to marketplace ideology and socio-historic or political and economic structures. I answer that call through this phenomenological research on women's experiences of changing social relations in Croatia's transition from Yugoslav exceptionalism to global neoliberalism.

Johnson, Thomas, and Grier (2017) argue that understanding the normalization of privilege can help explain the "power dynamics that exist within social groups - such as the 
hierarchies that fund privilege within categories of race, ethnicity, gender, class and sexuality" (2017, 3-4). In this research, connecting gendered subjectivity to changing marketplace ideology helps reveal the privileges implicit in ideology and state logics, and how new privileges become normalized or questioned through changing social relations among women from different generations and social classes. My theoretical approach allows for inquiry into the factors that lead to some women faring better or worse during privatization, and how changing privileges and logics become normalized in social relations.

\section{Everyday Consumption, Ideology, and Gender}

The domestic sphere - specifically, family meals - and work are ideal sites for learning more about how the power of marketplace ideology, given a specific role of the state, works to create new-gendered subjectivities and norms of socialization, yet they are often overlooked in consumer research, with a few exceptions (Zayer et al. 2012). These spheres "address connections between the agency of individuals, the role of political power in orchestrating daily life across a dispersed set of practices," (Luthar and Pušnik 2010, 2), both past and present. Memories of the past are at once insights into personal experiences and reflections of shared subjectivities (Halbwachs 1980). Memories also provide critical perspectives on the present (Todorova and Gille 2012). Comparing and contrasting retrospections and critical perspectives of older and younger women on work and family meals can provide insights into the normalization of gendered market subjectivity, in Zagreb. Likewise, comparatively exploring insights of women of a diversity of positions of employment and educational privilege similarly suggests 
ways that globalizing neoliberal ideology structures norms of social relations between and within these groups, and new privileges afforded by age, employment, and education.

\section{Yugoslav Exceptionalism as Marketplace Ideology}

Here, I provide a very broad overview of the historical periods of Yugoslavia, as they frame consumption and Yugoslav exceptionalism: labor and class equality, gender equality, and geopolitical independence: the break with Stalin, the Golden Era of Yugoslav consumption, and privatization.

\section{The Break with Stalin.}

The first historical period, 1946-1953, includes the break with Stalin and the USSR in 1948, the subsequent ideological shift in Yugoslavia, and post-war reconstruction, socio-cultural modernization, and industrialization. The break would mean that Yugoslavia would be both politically independent from West and East, yet also interdependent on Cold War tensions. For example, Tito accepted loans and engaged in trade with both sides of the Cold War. The constitution of 1953 institutionalized the political, economic, and civil liberalization that resulted from the break with Stalin in 1948 and the reforms to the League of Communists of Yugoslavia, including: worker's self-management of enterprises, and a turn towards decentralization of power via Republic-level economic and political control. Worker's self-management in firms and the ideological focus on the worker created a great degree of equality in social relations, especially compared to the pre-World War II order. The 1953 constitution established the social 
safety net: official guarantee of employment, housing, healthcare, pension, and education through grade 12 .

The Golden Era of Yugoslav exceptionalism and its demise.

The Golden Era is usually considered to be from 1964, when the economic reforms of the 1953 and 1963 constitutions and loans from the West came into effect, to the mid-1970s, when the global economic crisis left Tito suddenly unable to rely on his usual sources of funding from the West. In the Golden Era, consumer culture became a symbol of the state to demonstrate to citizens that the Yugoslav system was superior to both East and West (Patterson 2011; Sredl 2007).

In 1961, in Belgrade, Tito organized the Non-Aligned movement with Nehru, Sukarno, Nasser, and Nkrumah. The distinction between Yugoslav socialism and other socialisms in Europe during the Cold War is unique, as Yugoslav socialism suggests a specific geo-political subjectivity in which consumer life was better than the Warsaw Pact countries and less than Western European countries, and as more humane and free than either side of the Cold War divide (Sredl 2007). In the context of the geo-politics of the Cold War, exceptionalism supported a system of political power that was unique and significantly less totalitarian, when compared with the Warsaw Pact (1955-1991) countries. Yugoslavia issued passports and opened its borders in 1967. Returning home to Yugoslavia from Trieste or Graz, smuggling was ubiquitous, and informed the political subjectivity of Yugoslav consumer culture as somewhat second to the West, but better than the Eastern Bloc countries (Luthar and Pušnik 2010; Švab 2002). 
Feminism, as part of official ideology, was mostly focused on exalting the participation of women in the anti-fascist movement and the National Liberation Movement; attention to women in the movement, and to feminism more generally, declined after the reforms of 1953. However, women's education and literacy levels advanced greatly during socialism (Sredl 2009). The lived experience of gender equality was characterized by the triple burden of work outside the home and inside the home, plus child-rearing and other family care tasks such as meal preparation, for most women (Drakulić 1992; Einhorn 1993; Leinert Novosel 1990). An unofficial feminist movement in Yugoslavia began in Croatia in the late-1970s at the grassroots level among journalists and scholars; the state challenged the movement, based on the rational that women's rights had been achieved by the war and the state's official focus on equality (Barilar, Jelavić, and Prlenda 2005; Pavlovič 1999). Today, gender in Croatia is a complex issue of legacies of state socialist gender ideology and equality policies, cultural norms of gender roles, social stratification, post-war demographics, and imbalances in education and employment.

Tito's death in 1980, and the global oil crisis, changed the political dynamics of Yugoslavia. International pressure to repay loans in the early 1980s caused the economy and internal political dynamics to spiral into chaos, unemployment to spike, and exports and imports to cease. The Croatian independence referendum on 19 May 1991 was followed by official declaration of independence on 25 June 1991, and the end of official association with the Socialist Federal Republic of Yugoslavia on 8 October 1991. Croatia was granted recognition by the EEC on 15 January 1992. 


\section{Privatization.}

During the political and diplomatic process of independence, the Homeland War (1991-1995) began, creating political and economic turmoil, in addition to massive loss of life and damage to economic infrastructure. The government of the 1990s, and some would say after, managed the privatization process in ways that have been interpreted by many people in Croatia as pljačka hrvatske, the plundering of Croatia: characterized as selling assets such as the national telephone infrastructure, banks, and factories to allies of the political party in power, who often sold the companies to multinational corporations (Marjanović, Vuko, and Družijanić 2009; Petričić 2009). The new ownership of factories often forced employees of factories, mostly women, into retirement on pensions are were not adequate to support them in the era of global neoliberalism (Spajić-Vrkaš 2003). In contrast to the old ideology of equality, now, as a result of privatization, $15 \%$ of the population owns $80 \%$ of the wealth in Croatia (Ilišin 2007). Perhaps because of the importance of independence, or perhaps because of an implicit understanding that independence, democracy, and integration into European markets meant capitalism, the structure of the new Croatian economy and the process of privatization were not issues on the independence referendum. In the marketing scholarship on postsocialist Croatia, it remains to be understood how the ideology of global neoliberalism and the decline of the social safety net of the state came to be normalized in everyday social life, even as criticism of privatization is normalized through everyday terms such as pljačka hrvatske, the plundering of Croatia.

\section{Neoliberalism as Marketplace Ideology}


Neoliberalism, which I see as the new marketplace ideology in Zagreb, is a contested term that has been approached in various ways by various disciplines, from feminism to politics to history; in this research, I understand neoliberalism as referring to a global political-economic arrangement that favors free markets (Harvey 2005; Mirowski and Plehwe 2009). I view neoliberalism as a mentality of governmentality (Barry, Osbourne, and Rose 1996). Likewise, I view neoliberalism as a structuring structure that is centered on the market as taken for granted, as the private as having primacy over the public sphere, and as individualizing consumer responsibility for the self and the community in an era of a dwindling social safety net provided by the state (Brown 2006; Hall, Massey, and Rustin 2013; Giesler and Veresiu 2014). Within the structuring structure of neoliberalism, the individual is a middle-class, competitive entrepreneur, who is focused on emotional, physical, and professional selftransformation, self-work, and selfmanagement (Scharff 2014). Within the moral order of neoliberal selfhood, the abject, morally inferior "other" is constituted as powerless, not entrepreneurial, passive, dependent, and vulnerable (Brown 2003; Tyler 2013).

Feminist scholars such as Scharff $(2012,2014)$, among others, working from a position of neoliberalism as an organization of subjectivity, have argued that women, especially young women, are the ideal neoliberal subjects (Gill and Scharff 2011; McRobbie 2009; Ringrose and Walkerdine 2008). Their argument is built on a few interrelated assumptions, which I summarize here: the neoliberal emphasis on self-transformation and consumption is akin to cultural norms that feminize consumption and ask women to manage their selfhood, bodies, and sexuality, to be acceptable to men (Gill and Scharff 2011; Ringrose and Walkerdine 2008). 
For example, young women are often positioned in popular culture as the privileged beneficiaries of labor market equality and reproductive rights (McRobbie 2009). Likewise, young women are often depicted in ads, such as the Nike girleffect campaign, as the ideal objects of self-transformation and self-work through sport and consumption (Koffman and Gill 2013). Scharff (2014) has argued that the pressure on women in the neoliberal order tends to create heightened anxieties and focus on self-transformation among young women. In other words, Scharff (2014) and McRobbie (2009), among others, have demonstrated that young women experience pressures unique to their gender and generation under the demands of neoliberal subjectivity, in ways that replicate gender inequalities.

In Zagreb, a generation of women (Gen III) came of age during privatization; I view them as embedded in the priorities of neoliberalism. In socialist Yugoslavia, women working in factories were the ideal subjects; their subjectivity is represented by Gen I and Gen II. I am interested in studying the tensions between Gen III and Gens I and II as a way of understanding how the new subjectivity creates new privileges and/or replicates or changes longstanding ones, such as access to higher education. Thus, I interview informants from these generational cohorts. Beyond the context of this research, this work has implications for understanding the relationship between neoliberal logics, the state, and gendered market subjectivity, which are relatively unexplored in the literature on gender, consumption, and markets.

\section{Methodology}

The methods employed in preparing this interpretivist research include depth interviews and participant observation. Data collection was informed by prior scholarship on post-socialist 
transformations and the iterative process of gaining insights in the field, and then exploring them further with subsequent interviews. Like the work of Tumbat and Belk (2011), data collection developed in two stages. The first stage took place in Zagreb, from October 2002 to May 2003. This early stage of research was necessary, since everyday life and consumer practices in Croatia before and after 1991 tended, in 2002, to be an emerging rather than established area of marketing research (Patterson 2011, 7). The goal of this stage of research was to learn, through open-ended interviews with informants accessed through a convenience sample, how consumers experienced privatization, in order to develop ideas to explore in the second stage of the project. A related goal was to find four key informants who could discuss emerging themes in the research and theory building, in both the first and second stages of research (Wallendorf and Belk 1989). Informants directed my attention to the new social inequities of privatization, in the forms of the social differences between people who thrived and who suffered during privatization. I pursued this theme in the second stage of fieldwork in Zagreb, which took place from November 2006 to June 2007. Data and procedures represented in this manuscript refer to the second stage of research.

All informants were accessed via snowball sampling through friends and family, and the four key informants. Accessing informants through a shared contact helped establish rapport (IzberkBilgin 2012). Likewise, my liminal position in the field, as a scholar and as a member of the Croatian Diaspora, helped establish rapport in discussing questions that are politically sensitive. All informants were assured of the confidentiality of their identity. Pseudonyms are used in this research, and identifying information is altered, except student status. Interviews were conducted by the author, in Croatian or in English, took place in informant homes, offices, or neighborhood 
cafes, were recorded using digital audio recorders, and lasted an average of one hour. Informants, at times, were reluctant to participate in interviews with an audio recorder, probably as a consequence of the tendency towards mistrust that developed during Yugoslavia. In those cases, field notes written post-interview served as a record (Tumbat and Belk 2011).

Participants were sought from three generational cohorts, based on the assumption that a person's age during a significant historical period would influence his or her experience of privatization (Harrison et al. 2011). The three generational groups are: Generation I, who were born between 1940 and 1961 and experienced the development, affluence, and decline of Tito's Yugoslav exceptionalism, and subsequently, independence and war; Generation II, born between 1962 and 1980, who experienced the affluence and decline of Yugoslav consumer culture and the changes of the 1990s, and Generation III, born between 1981 and 1985, who knows only of the decline of Yugoslavia and its transformation.

Because this research is interested in consumer experiences of macro-level change, retrospective methods, as explained in Otnes et al. (2006), were applied to data collection with Generation I and II. Retrospective methods emphasize a phenomenological, as opposed to a chronological, exploration of the past as it relates to the present (Otnes et al. 2006). Some scholars might argue that a limitation of retrospective research is that it is subjective, because it relies on human memory, which tends to be biased by contemporary events, to build interpretations. Also, the emphasis on specific events has been noted as a shortcoming of retrospective approaches to studying the past. Yet advocates argue that these two characteristics - a phenomenological exploration of the past and change, and the subjective nature of retrospective interviews - are the strengths of retrospective interviewing (Otnes et al. 2006). 
They allow for a phenomenological connection between the past and the present (Otnes et al. 2006).

Interviews sought to help Generation I and II informants form narratives of the past that "recapture time" (Otnes et al. 2006, 394). Retrospective anchoring and profusion were used to help informants return to the past (Otnes et al. 2006). Grand-tour type questions about the informant's history as it relates to major political events served as a cue to prompt informants to remember the past (McCracken 1988). Interviews proceeded to open-ended, nondirective questions about work, socializing, and everyday consumption of the daily meal, then and now. The everyday family meal was a focal point in all interviews, as it was once a widely held social practice, yet it is now in flux. Interviews with two Gen I and Gen III mother-daughter dyads were conducted to access any potential tensions in generational experiences of privatization. One dyad is represented in this research.

Generation III informants were interviewed in small groups of peers (rather than alone). Undergraduate students at the University of Zagreb, Faculty of Economics, Department of Marketing, were recruited voluntarily. Over a period of two weeks in April 2007, they were interviewed in five groups of three informants each, in an office in the Department of Marketing. A criticism of small group interviews is that group think can emerge. However, in this case, group think led informants to frequently follow-up on the comments of another informant by noting exceptions. Thus, the small focus groups were more a cross between a focus group discussion and individual interviews. Furthermore, the small group setting also helped overcome obstacles inherent in student-professor interactions in Croatia. Social norms of hierarchy would probably prevent students from speaking openly with a professor. Of the 15 Generation III 
informants from the University, who participated in this research, one is represented in this manuscript.

Informants are from working-class, middle-class, and upper-middle-class Zagreb; informants self-identified by class and origin. Class, generally understood in the consumer behavior literature to structure consumption, is relevant as it might influence how consumers experience the change in consumer culture temporality brought by privatization (Arnould and Thompson 2005).

The neighborhood in which a person lives, urban or rural family origins and duration of living in a city, a person's level of formal education and the formal education level of one's parents, employment as a professional or as a laborer, and the employment of one's parents, form the elements of general understandings of social class in Zagreb (Sredl 2007, 2009; Sredl and Renko 2009). Data collection included working with 45 informants (including the key informants). However, this manuscript represents 10 informants (and no key informants), whose views and experiences are most representative of informant experiences generally (Izberk-Bilgin 2012).

Data analysis started in the field, through member checks with key informants (Belk, Wallendorf, and Sherry 1989). After returning to the US from the field, I employed 3 native speakers of Croatian to transcribe and translate the 17 hours of interview audio files generated from data collection. The transcripts generated 600 pages of text. Transcripts were analyzed using a hermeneutic and an iterative approach (Thompson, Pollio, and Locander 1994). A critical position towards the informants' underlying assumptions and categorizations of the world presented in the interviews was maintained while reading transcripts (McCracken 1988). After 
reading each transcript, I listed important words and abstract themes that emerged in the interview. After reading all of the transcripts and making notes, I studied my notes for patterns of association and assumptions across the interviews. I then sought differences and similarities between the analytical categories of gender, class, and generation, and discerned emerging themes specific to a category. In the next stage, I linked the themes back to quotes from the interviews (McCracken 1988). Field notes were re-read for their potential to challenge or to support emerging themes, or suggest alternative interpretations. Interpretations were explored with key informants to explore potential negative cases (Miles and Huberman 1994).

\section{Findings}

Three themes emerge in the findings: Autonomy, The Privilege of Generation, and Emotional Subjectivity. In the first section of the Findings, Autonomy, the responses of Gen I and Gen II Mothers suggest the ways that they respond to neoliberal ideology and its demands for autonomy and self-transformation are through more individual activities for children after school and, for adults, working longer hours, especially through the old lunch time of $4 \mathrm{pm}$. A consequence of the new ideology and individual responsibility for employment, as opposed to the full employment of Yugoslav exceptionalism, is that the shared experience of working or middleclass consumers, all of whom ate lunch at home at 4 pm, which was part of Yugoslav exceptionalism, has diminished. As such, the new subjectivity of Mothers is focused on individual self-management as well as family self-management: managing schedules of children, activities of children, and one's own work and hours. This management become a discursive 
performance of the new autonomous, self-managing woman, who, as in the past, is still responsible for family care.

The second section of the Findings refers to the ways that new subjectivities and social relations are expressed in the tension-filled Gen I and Gen III interactions surrounding the family meal. This section, titled The Privilege of Generation, suggests that Gen III women are the beneficiaries of increased access to University education as well as jobs in the sciences, as their Gen I Mothers were in the past, in the Yugoslav ideology of gender and labor equality. Yet the new, subjective position of neoliberalism means that University study is an individual path to the professional class that requires an autonomous self. This autonomous subjectivity is in contrast with the old Yugoslav female subject who is self-sacrificing for the family and for the factory. The ways that Gen I women are "left behind" or seen as powerless and Gen III women are privileged come together in tensions over the daily family meal.

Finally, in the third section of the findings, Emotional Subjectivity, working-class and professional women share a gendered emotional subjectivity of neoliberalism. Even though professional women come out of the old system with similar or increased privilege, and workingclass women are now excluded from the system, both groups experience lost pride. Workingclass women experience the loss of pride through their unemployment or their labor in the unofficial economy. For working-class women, their diminished status and financial insecurity creates feelings of a lack of worthiness to participate in social life (in addition to a lack of funds to socialize). For professional women, work days are now too long, and work terms too uncertain, to accommodate socializing after work. Professional women see their position in the global labor economy as diminished, and uncertain, as they are now "cheap labor" for Western 
European firms, instead of participants in the worker's democracy of the geo-political Yugoslav state. For both groups, the new ideology brings new feelings of uncertainty and anxiety as well as lost pride. Based on these findings about the sense of loss and new uncertainty, I suggest that the new ideology brings a new emotional subjectivity, normalized through less socializing than in the old ideology.

\section{Autonomy}

Lina, (Gen I), upper middle class, professional, provides insight into the ways that Yugoslav marketplace ideology created socially shared experiences, in this case, of work hours and family meals.

Interviewer: What are some of the things that you remember about having friends over?

Lina: I can say that we had a lot of, we had a very rich social life, richer than today and we also prepared a lot of good things. In Croatia, it is a tradition to eat well. So we, all the time, we spent a lot of our money, I remember all the money, on food. So social life was really, very rich. We met with our friends, with our family, which was really very big, every day, almost every day. Because we didn’t work too much.

The Yugoslav exceptionalism ideology created a generally shared way of relating to the world, as well as structures in which that orientation could be lived out, that focused on the collective. That is, the system favored full employment over getting ahead, so, for at least professional women, there was time and money for socializing. Socializing was the generally understood way of doing things.

In the next quote, Dunja, upper middle-class, Gen II, compares the uniformity and 
shared experience of after-work and after-school lunch when she was a child, in the mid to late-1960s, to today's individualized, autonomous after-school and after-work activity. For example, before, it doesn't matter that those women [Mothers] were working, the table was the central place of the house. Working time was from $7 \mathrm{am}$ until 3pm, and at 4pm, almost everyone was at home, and gathering was for lunch time. My friends who now have [young] children, they do not meet their children because she comes home early, another one comes in another time, he has English classes, this one is swimming. So, there is not that culture of the table, of meeting.

Dunja's comparison and contrast supports Lina's suggestion that ideology is associated with both a structure and a way of thinking and acting that was shared across society, for the most part. Dunja also implies that the old system reproduced hierarchies of gendered inequality: women were responsible for working, for home, and for maintaining the "culture of the table." Now, neoliberal ideology asks women to work and to be responsible for the now individualized task of raising children who can become autonomous self-managers, make choices, and achieve through independent efforts. After-school lessons, both their content and the act of taking individual lessons, implicitly makes these children more competitive in the labor market, due to their individual skills and their familiarity with individual transformation. I suggest that when parents are raising autonomous, self-managing children, and coming home at different hours, compared to the uniform working hours of the past, they are both accommodating the responsibilities of globalizing neoliberalism, and habituating the children to the new subjectivity as well.

Vanda, an upper-middle class, Gen II informant, also talks about responses to the pressures of the new ideology, in the context of social relations around the meal:

Interviewer: What sorts of things did families like yours used to do in the dining room? 
Vanda: When this new Yugoslavia came, after the Second World War, it all started to change. Then, parents would come home from work, rather early for today's standards, because they would work until 4 or 3 , and they would be home in the late afternoon, and they would eat, and the whole family would eat together at dinner time. So now, depending on how the household functions. We have a midday meal, all together. But now since the [step] son started working late hours [he's 27 years old and an advertising copywriter in a global firm], he comes and has dinner at a weird time, after work. It is difficult to say what the real tradition is now, because everything is changing.

Interviewer: How often does he come for dinner?

Vanda: He comes as often as he can, because he lives alone, and cooking is out of the question, because he works from 9 to 6 , and he is dead tired when he gets off work. He comes to have a cooked meal [cooked by Vanda], at least once a day, and we all [Vanda, her husband and their 10-yearold daughter] sort of hang around, because you have to make the best of the time that you have, so we all sort of are around when he comes. So that is a family meal in which one eats, and others are just present, which is also strange.

When Vanda discusses the habit of her adult stepson coming home for a meal at $6 \mathrm{pm}$, she adds to Dunja's implication that changes in the meal are responses to the ideology of neoliberal individualism. Now, unlike the past Lina speaks of, one must work in a way that is autonomous from social relations of the family. Finally, but not least important, now, the practice of the meal depends on "how the household functions" rather than a pattern across society, set by working hours and socio-cultural norms, as it did in the past. In the case of Dunja and Vanda, how the household functions is an outcome of new demands for longer working hours, coupled with a 
lack of employment security. Another factor influencing how the household functions is the autonomous activities of the children, which are, generally speaking, activities that provide them with expertise.

Now, upper-middle-class mothers, those with enough privilege to afford activities for their children, are managing their careers and the autonomous activities of their children. Their management, I argue, is a form of discursively practicing the new ideology of neoliberal autonomy, self-management, and individualism. The new subjectivity of Mothers organizing individual activities and family meals around new autonomous workers and children raised to be autonomous seems to replicate old inequalities in which women were responsible for working, for home, and for maintaining the "culture of the table." It also creates potential new inequalities between children of parents who can afford to adjust to the new logic, and those who cannot afford the lessons.

\section{The Privilege of Generation}

In this section of the findings, I focus on the tension between Gen III daughters and their Gen I Mothers surrounding the daily family meal context. I use this context as a means of understanding how the process of socializing into a new structuring structure is experienced differently by women, depending on their generational cohort, or age at the time of privatization. This comparison also reveals the ways that changing ideologies may privilege some generations over others. 
Andrea is a Gen III, working class, University student who lives in her parent's apartment, as is typical in Zagreb. Andrea's Gen I Mother (not participating in the interview) worked in a factory, until she retired, during privatization.

When we eat all together [both parents, Andrea, and her brother] at the table, over the weekend. It's just sometimes it bothers me that my mom, throughout the week, she feels bad when I come home and say I ate. And she feels bad, so she feels like she has to cook in the evening. And then we have to eat in the evening. I don't like that. But that's why during the weekend, it's great. Everyone just ... as soon as the food is on the table, right away, everyone comes, and you know, we all go to eat. Andrea's description of tension with her mother surrounding when and how they might meet at home is replete with the guilt that might be a typical example of tension between a young adult child's growing independence and a mother's concern for the health and welfare of that child. Yet, in the context of changing market structures and ideology in Croatia, this tension also illuminates the generational and gendered differences in old and new subjectivities. This tension is pronounced in the dyadic interview with Franka and her daughter Elena.

Franka (Gen I, middle class, professional working in the sciences) and her Gen III daughter, Elena, a University student living at home, discuss their family’s weekday and weekend meals.

Franka: We had time for the family [in the past]. And now we don't because of the hours. And our work isn't organized where we [family] have a meal together.

Interviewer: Now, do you try to eat dinner together?

Franka: Well ... yes, we try. I mean, when they [her two children] were little Sunday was always the day to sit down and eat together. Sunday you always had to sit at the table. And I was committed to that for a long time. Now, it's just us two. Of course, now it's a little harder. For quite some time, we would sit and eat together. 
Elena: We hardly do that now; we are too busy, not sitting and eating together.

Like Andrea's description of her mealtime ritual with her mother, tension runs through this conversation. However, in this family, Sunday does not offer time together because the family members, namely, Elena and her Gen II brother, are too busy on Sunday for the meal. Education and participation in labor and the professions for women did advance in the era of Yugoslavia, although inequalities continued, and Franka is a beneficiary of that modernization process, as she works in the professions. An emphasis in state socialist feminist ideology was formally educating women and bringing them into the professions (Sredl 2009; Sredl and Renko 2009). For example, in 1961, of the population completing high school (no University), $6.8 \%$ were women and $19.4 \%$ were men. In 2011, the figures were $45.9 \%$ and $60 \%$. In $1960,31.8 \%$ of University graduates were women and $68.2 \%$ were men. In $2014,59.9 \%$ of University graduates were women and $40.1 \%$ were men (Croatian Bureau of Statistics 2016). After privatization, women in Croatia compose $50.6 \%$ of students in science, math, and computing and $28.7 \%$ of students in engineering, while the percent of women students in these fields in other European Union countries is $37.6 \%$ and $25 \%$, respectively. Women make up $62 \%$ of the total medical doctors, and men 38\%, in Croatia in 2014 (Croatian Bureau of Statistics 2016). Yet the percent of women in management positions in large companies and small to medium sized enterprises is 22\%, compared with the EU average of 33\% (European Commission 2012).

Likewise, there is a strong gender bias evidenced in the distribution of occupations, with women tending to work in "typically female" professions such as education or retail and men working in "typically male" professions such as manufacturing and construction (European Commission 2012). In 2014, in the highest earning employment sectors, finance and financial 
services, women's salaries were 76\% of men's salaries (Croatian Bureau of Statistics 2016). The opportunity for women to succeed in the professions is increasing, compared to the past, and women are pursuing those positions, starting with University education (European Commission 2012).

Gen III women are the beneficiaries of increased access to University education and decades of socialist gender equity policy in the Universities. They also benefit from globalization, as it has brought more potential jobs in the sciences and professional services. However, they also face the threat of failure and relegation to work in the services industry, where they will be exposed to the new limitations that come with lower wages than the professional class. The new ideology emphasizes a woman who is the beneficiary of new opportunities and equality in the labor market, placing responsibility for success in this new market on young women (Scharff 2012). To prepare for the competition of the job market, the subjective position of University study as a path to the professional class requires an autonomous self. This subjectivity is in contrast with the old Yugoslav female subject who is self-sacrificing for the family and for the factory. Gen I women did benefit from socialist gender ideology in education, yet the ideology of employment in the past did not require an autonomous self that prioritizes study over social relations. Furthermore, Gen I women are often retired early or later in their career, and might not see opportunity for advancement in an equal labor market, as it is offered by the logics of neoliberal labor market ideology. Their exclusion from this logic and the associated subjectivity it requires seems to put them in at odds with their daughters over the daily meal, and left out of the new ideology. Linking the tension over the meal to ideology shows the 
ways that they are left out of global neoliberalism's privileging of young women, as opposed to their failure to become responsible for their success in the labor market.

\section{Emotional Subjectivity}

The old workday started at 7 am and ended at 3 or 3 pm for most people. In a system of full employment, moonlighting might seem counterintuitive (Rubić 2013). Yet wages were low for the working class, so moonlighting was not unusual. Moonlighting, according to my field notes, involved working a second job, often unofficially, after working an official job from 7 am to 3 pm. For example, a woman might work as a laborer in a factory during the morning and as a house cleaner in the afternoon. Given that small enterprises were not uncommon, a laborer might combine expertise by, for example, working as a laborer in a state-run meat processing plant during the morning, and working as a butcher for a privately owned small butcher shop in the afternoon.

As my field notes indicate, it was often the case that good housing was difficult for workers to find, as there was usually a short supply of housing. Likewise, most workers were migrants to Zagreb from villages, so they had no housing in the cities to inherit (many locals inherit their home). As if it were a material manifestation of the lack of access to loans and their access to cash from moonlighting, and their class position, many working-class people tended to build (unregistered) houses room by room, living in the first room completed, according to my field notes.

Working-class, Generation I informants, Matrina, Sanja, and Vera, worked on the production line at a factory, located in their neighborhood, from 7 am to 3 pm daily. Martina's 
husband worked as a truck driver, often driving to and from Germany. Sanja worked a second job in the afternoon as a house cleaner. Vera took care of the children and the home after work. Vera's husband worked as a butcher in a state enterprise from 7 am to $3 \mathrm{pm}$, and then in the afternoon as a butcher in a private enterprise. All three families built or began to build their own homes in the old order, largely from moonlighting income.

In discussing socializing in the past, Martina remembered going to the movies frequently. Sanja showed me photos of her family on their summer holiday in the village of Bol, on the island of Brač, where they stayed in a now abandoned hotel that was owned by the now closed factory where she worked. Vera talked about buying Burda, the German patterns magazine, in Croatia, and sewing their children's clothes at home on weekends. They all spoke of the collegiality at work, which has been noted in prior ethnographies of women's experiences of state socialism in the GDR (Berdahl 1999).

Martina, Sanja, and Vera accepted early pensions with the privatization and closing of the light bulb factory where they worked. Sanja's former moonlighting job as a house cleaner in the past (usually working in the homes of professional women, some of whom are still her clients) is now her main source of income. Martina began cleaning houses when the factory closed. Vera's health prevents her from working at all. They all live in the same houses as they did before 1991, except Martina. She, her husband, and their daughter live in housing provided by the state for unemployed or pensioner veterans of the Homeland War (her husband). They live on her husband's meager pension from the state, her pension, and her income as a house cleaner.

In the following retrospection, Martina, working class, Generation I, compares social relations in the past and now. 
Interviewer: Would you say you had more friends visiting your home back then?

Martina: I would say yes. Back then, it seemed people were calmer. With work and life in general. There was more time for people to go see each other and have fun. It was different back then. Today, nothing is for sure.

I suggest that moving from working as factory workers to house cleaners, a sort of "independent" non-contract, temporary, low prestige work in the informal economy, has changed the subjective experience of being a working-class woman in Zagreb. Now, the economy does not have as many factories, and the ideology valorizes middle-class women who can participate in the official labor markets through their autonomous efforts at self-transformation. For example, in the past, the ideology valorized female, working-class labor, and the state supported the factories in which many working-class women worked. Working in the unofficial economy, or moonlighting, was socio-culturally associated with achieving the goal of building a home. Now, for formerly working-class women, laboring in the unofficial economy is a sign to themselves and to others that they have been left out of the new system, that the new ideology has failed them, by taking away their jobs and the old set of socio-cultural meanings of status that came from participating in the formal and informal labor market, such as being a good Yugoslav laborer and a moral righteous Croatian woman who sacrifices to build a family home.

In addition to the subjective loss of status and moral position that came with the working class, female Yugoslav experience, these women experience participating in the informal labor market as highly uncertain and full of anxiety, given that their work is contingent, and that the old social safety net of the factory and the state are gone. Kuruoğlu and Ger (2014) demonstrate that emotional habitus describes a common emotional orientation and disposition to seeing the world. To further their argument, I suggest that the emotional aspect of Yugoslav subjectivity, 
for working-class women in Zagreb, has changed from one of pride to one of shame and exclusion, as ideology and structures changed, and these women are no longer able to participate in the formal labor market. The effect of privatization and the globalization of management emphasis on control and accountability on the subjectivity of factory floor workers in a privatizing company has been explored in prior research (Dunn 1999, 2004). I add to that work an examination of working-class women in the unofficial labor market, and demonstrate the ways that their new, neoliberal subjectivity includes an emotional component of anxiety and shame.

While working-class women lost status as the structure and ideology shifted away from their labor market position in Yugoslavia, professional women, who are less explored as a subject of research on post-socialism (Dunn 1999, 2004) than working-class women, have succeeded in keeping their status. In general, jobs of the female professional class were not eliminated during privatization. Instead, with global neoliberal ideology, the professions came to be valorized along with the valorization of the entrepreneurial spirit, self-managed lives, and self-application. However, like working-class women, their new subjectivity comes with new, difficult emotions, namely, lost pride, in the face of the new pressures and uncertainties of neoliberalism.

Irina, upper-middle class, Gen I, worked for a state-owned marketing firm before 1991; she was the director of that privatized firm at the time of data collection. During privatization, a global firm bought the state-owned firm. She gives us insight into the ways that the new economy in Croatia creates a specific emotional subjectivity for professional women working in the professional services in Zagreb. Irina provides comparison between her professional 
experiences in the past with those of her daughter, a Gen II analyst at the local office of a global finance company. Irina also compares professional work arrangements in Croatia to those in Germany because in Croatia, people often use Germany as a trope for an ideal economic and social structure.

Interviewer: Do you miss small things [elements of the family meal] from before?

Irina: $\quad$ To be honest, today I see something that looks to me like a deviation, which, I believe, is not [happening] in the US, Germany. It is that multinational companies came and opened their branches and use the situation. We have educated people and very competent youth and they keep them much longer than from 9:00 a.m. to 5:00 p.m. They work a lot, for example, my daughter works, and never comes home before 12:00 a.m. I think that they cannot do that in Germany, and if they work like that, then they have to pay overtime. Here it became common to work without overtime pay. The socializing is missing nowadays. We worked overtime only from project to project [at the marketing firm]. It was not regular to stay till 12:00 a.m. It was something that we wanted to do. This thing today seems like obligation. I think that today there is not a work that is paid well. My daughter has a good salary, but most of the women there have 4000-5000 Kuna, which is 500-600 euro a month [average salary in Croatia at the time of this research]. And they work 12, 13, 15, hours a day. That is not good.

In this set of power relations between multinational employers and local employees in Zagreb, even for those at the level of mid-management, like Irina's daughter, the state offers no protection for workers against their employers, and demands very little employee rights from employers, as evidenced in salaries, uncertainty, and long hours. The privatization of the professional services sector in Zagreb brought a sense of self as someone on the global 
periphery, based on wages and uncertainty of continued employment. The idea that a professional woman in Germany would be paid better and work fewer hours, and have rights, may or may not be accurate. It may be a contemporary application of the Yugoslav idea that things were better in the West (Luthar 2006).

Yet the point is that the old sense of security is gone, and the status of being part of a distinct system, that was unique in the world, is gone. The subjective experience of professional women in the globalized services sector in Croatia as cheap, replaceable labor suggests a new emotional subjectivity, normalized through changing social relations, I argue. For professional women, the new subjective loss of status is felt as a self whose work, education, and ideas are worth less than in other countries, is easily replicable, and must, therefore, work more hours, which only reinforces the sense of lost status. While upper-middle-class women are "better off" than working-class women, as the new ideology privileges their employment and has no room for the former laborers, the two groups share the emotional subjectivity of uncertainty, loss, and marginalization that comes with living at the periphery of Europe's globalizing neoliberalism.

\section{Discussion}

The transition from the market ideology of Yugoslav exceptionalism to global neoliberalism in postsocialist Zagreb provides an ideal context for this study of the discursive power of marketplace ideology. I use retrospection, oral history, depth interviews, and small group discussions as sources to compare past and present gendered, subjective experiences of changing social relations, surrounding the daily meal and work, between generational cohorts and class positions. The Findings demonstrate that market ideology, along with its relationships to the 
state, creates types of gendered consumers, and that gendered consumer subjectivities, as a function of acting within ideology and structure, influence patterns of social relations that, in turn, normalize the privileges and exclusions of marketplace ideology and its related politicaleconomic structure. The normalization of subjectivity, in turn, is a means of becoming a self in that structure, and consenting to being a subject in that structure.

In the first section of the data, Autonomy, we saw upper-middle-class Mothers make choices related to the individual activities of their children after school. These choices at the level of the individual are a contrast with the Yugoslav shared, middle-class experience of almost everyone eating lunch at home after work. The individual activities, and how they replace the table as the center of the house, are a contrast with the socially shared experience of lunch. Making these choices, doing these activities, and adapting to changing meals is an example of the ways that these women and their children adjust to and normalize the autonomy required from neoliberalism. As these choices are largely within the realm of possibility for families with higher income, in other words, in the professional classes, the autonomy, self-improvement, and self-management of neoliberalism creates new social divisions between those Mothers and children who have the resources to choose individual activities, and those who cannot afford to make those choices. As these differences emerge, and agency is increasingly expressed through individual choices of consumption of children's after-school activities, which in turn make them better adapted to the autonomy of neoliberalism, I suspect that neoliberal ideology reflectively directs a new subjectivity in which individualism and autonomy become the norm for financially privileged Mothers and children. Likewise, new social class differences emerge between those who can afford to make these choices, and those who cannot. Finally, the responsibility of 
managing the new selfhood and its effect on the family continues to fall on Mothers, replicating gendered inequities of the past.

In this research, the pressures of the new ideology of individualism and the dwindling role of the state seem to force the informants to engage in individual activities, from work to individual instruction for children. Maintaining the family meal tends to be understood in much of the family studies literature as a responsibility of a family, rather than seeing families as functioning under social pressures (Daly 1996). For example, much of the consumption literature on time and the family tends to look at the practices of individual families, and takes the form of measuring time spent on tasks, given a North American, heterosexual family (Strober and Weinberg 1980; Soberon-Ferrer and Dardis 1991). However, future research on family meals and time, and the question of work-life balance more generally, might benefit from looking at family as socially situated, and subject to pressures of a system and its ideology, as opposed to autonomously making decisions about how to spend time. An approach that looks at families as socially situated, could allow for an examination of the ways that market ideologies of the individual and individual responsibility frame family interaction (Epp and Price 2008) and concepts of work-life balance and the ways that they frame consumption. Similarly, connecting what happened in Zagreb with global trends allows us to take insights from this context and use them in future research that situates consumption in emerging markets within the structural arrangements of neoliberal capitalism (Askegaard and Linnet 2011).

In the second theme of the Findings, Privilege of Generation, the tension between the generations might be easily understood as those women who are older and failed to adapt because they were too embedded in the old system, verses those women who are young and who 
managed to adapt, by taking advantages of new opportunities in the labor market, through gaining a University education as a form of preparation. Tension in social relations surrounding the daily meal, however, reveals the ways that young women must take responsibility for the risks and opportunities of the more demanding job market, by spending time studying. The privilege of being the beneficiary of the new ideology comes with the individual responsibility for success in the labor market. Likewise, the tension between generations suggests that the new ideology, with its logics of career advancement, does not favor women who have matured in their careers: perhaps they are not beneficiaries of labor market equality, and perhaps it is not practical for them to try to advance, if retirement is imminent.

Many scholars of gender, including Scharff (2014), suggest that neoliberal ideology positions women as "subjects of capacity on the one hand" and offers "intensifying forms of governmentality on the other" $(2014,2)$. In this dichotomy, women who meet the demands of neoliberalism are empowered, and those who do not are passive victims of the patriarchy (Scharff 2011). We may see in consumer research some of this tendency to separate female consumers, especially in post-socialist states (Coulter, Price, and Feick 2003), into categories of succeeding or failing to adapt to new consumption identities. In contrast, in this research, rather than focusing on the individual and notions of adapting to brands as signs of successfully adapting to post-socialism, my object of inquiry is ways that consent for the new neoliberal ideology and state structure takes place through changing social relations. Thus, we might see that, rather than adapting or failing to adapt, there are new privileges, which mean that some consumers (younger women) and not others (older women) are included in social relations, and that privileges are normalized. 
In the third theme of the Findings, Emotional Subjectivity, I compare working-class and upper middle-class women's experiences of the labor market during and after privatization. Both groups of women experience globalizing neoliberal subjectivity as full of anxiety and uncertainty. They also experience a loss of the pride that was associated with the Yugoslav subjectivity and being part of the ideology of Yugoslav gendered labor and its geo-political position. Yet the new structure and ideology shuts working-class, Gen I women out of socializing because they do not have money, they feel the future is uncertain, and they now feel their subjective position somewhat shameful, as they are left out of the new labor market. The new ideology provides professional women with continued privileges and new anxieties and feelings of lost pride. Thus, the gendered subjectivity of neoliberalism in privatizing Zagreb includes an emotional element, soaked with anxiety and a sense of diminished global status as a worker or professional.

The new anxiety and demands on the self, due to the uncertainty of work and end of the social safety net of the state, erode the old practices of socializing, for working-class and uppermiddle-class women. It is possible to suggest, based on this research, that marketplace ideology is also a gendered, emotional subjectivity. Likewise, emotion operates here as a technology of governmentality. The old norm of socializing which was possible and normalized because of the limited demands of the system on the self, as the state took responsibility for providing for education and employment. Now, socializing is an individual choice or responsibility, bringing broad change in culture. While socializing is less normal, it is possible only for those who experience the new emotional subjectivity with the emotional and financial capabilities to engage in socializing. This gendered emotional subjectivity is what Scharff $(2014,2)$ calls an 
"intensifying form of governmentality," as it creates a self that is a product of the new order, and its actions in social life are constrained by the structure.

Likewise, the autonomy, independence, and self-monitoring required to succeed in neoliberalism as a woman tends to reproduce or to create privilege. As we saw across the three themes of the findings, across social groups of generation and class, consensus is established, the power of the new ideology is secured, positions of status are delineated, and privilege is normalized, when informants from these groups make everyday decisions about consumption and labor, such as the Mothers who enroll their children in swim classes after school and in the process give their children advantages, or the University students who study rather than come home to eat the family meal and in the process see the older generations as an other, and the professional and formerly working-class women who are now too stressed to socialize.

For scholars interested in the specific social dynamics of privatization in Croatia, or other privatization processes in post-socialist states in Europe, this paper highlights the importance of interrogating the normalization of global neoliberalism, the declining role of the state in providing a social safety net, and the transformation of and disruption to old privileges. As I believe I have demonstrated, such a perspective enhances understanding of some of the social inequities that have arrived after privatization, such as income inequality, social exclusion, and changing forms of gender inequality in the labor force. This perspective on globalization also implies that global neoliberalism is something that requires consent, and that achieves consent discursively, as opposed to a natural state of being or progress after state socialism, to which consumers must adjust. 
This research highlights the importance of intersectionality in generating research results that are more "inclusive, precise, and radical" (Gopaldas and DeRoy 2015, 333). By presenting results that highlight intersectionality, this research challenges the invisibility of working-class women or older women in emerging markets. This work also represents the richness and diversity of local culture (Gopaldas and DeRoy 2015). By focusing on the disruptions and continuities in transforming subjectivities, from differing class and generational positions, we can understand the importance of intersectionality and governmentality for further research on market ideology and globalization.

\section{Further Research}

The goal of this research was to delve deeply into women's class and generationally based experiences of privatization and to link those experiences with old and new ideologies and the changing role of the state. In comparing and contrasting the old and new patterns of social relations between groups, themes of autonomy, privilege, and emotional subjectivity emerged. Given that Zagreb is $18 \%$ of Croatia's population, by design, this qualitative research does not aim to capture a sample of informants that would be representative of the entire Croatian population (Croatian Bureau of Statistics 2011). Yet, I maintain that what happened in Zagreb is indicative of changing social relations in other post-socialist capitals in Europe, as marketization, and the diminished role of the state in creating equality, brought new, gendered ideologies of class and labor. However, given that Zagreb's population is only $25 \%$ of Croatia's total population, it is difficult to imagine that the urban trends of women in Zagreb's working, middle, and upper middle classes reflect the social relations of the less privileged, rural population of 
Croatia: $41 \%$ of the population of Croatia lives in rural and $59 \%$ in urban areas (CIA World Factbook 2017). An important topic for future research is the dislocations privatization has brought to Croatia's rural population of men and women. Likewise, the global economic crisis of 2008 and its aftermath, as well as the accession of Croatia into the European Union on July 1, 2013, surely have influenced concepts of labor, gender, and social relations in Zagreb, as well as across Croatia. Thus, the role of these two macro-level events on the daily life of consumers, on cultural norms of labor, on gender, and on markets in Croatia and neighboring countries, presents a promising area for further research on globalization and other substantive topics related to consumption, markets, and culture.

\section{Conclusion}

Recent research on marketplace ideology has called for greater attention to ways that the logics of the state and of market ideology discursively influence consumer subjectivity and fields of action by locating consumer experiences in the logics of structures and ideologies. In this research, exploring consumer subjective experiences of changing social relations amid a dwindling state-provided social safety net and changing market ideologies demonstrates that changing, everyday social relations normalize the gendered subjectivity of neoliberalism in Croatia. That subjectivity is characterized by autonomy, the privilege of the younger generation, and the emotional subjectivity of anxiety and loss, discursively normalized through changing social relations. These findings have implications beyond the context of Zagreb. For scholars of globalization, who are interested in the ways that the globalization of neoliberal ideology reproduces and challenges local social privileges, this paper provides insight into the changing 
role of the state in that process. For scholars of the socio-historic patterning of consumption, who look at a breadth of contexts in their exploration of the dynamics of change at the structural and everyday levels, this research shows that consent for governance is discursively created through normalizing processes such as everyday social relations. For scholars of gender, ideology, and consumer behavior, this research suggests that global neoliberalism operates discursively through a new emotional subjectivity of anxiety, normalized in declining social relations. Finally, by comparing subjectivity in two contexts, marked by contrasting state logics, future research on marketplace ideology can explore other contexts to further understand the ways that the logics of the state and marketplace ideology direct market subjectivities and the ways that social relations discursively normalize those logics, inequities, and subjectivities.

\section{Acknowledgements}

The author thanks Jonathan Schroeder, Editor at Large at CMC, and the anonymous reviewers for their insightful comments on this article. This article is based on my doctoral dissertation at the University of Illinois at Urbana-Champaign; I thank Cele C. Otnes and Michelle R. Nelson, dissertation co-chairs, and Zsuzsa Gille, committee member, for their work as mentors. I recognize and thank the International Research and Exchange Board for the IARO grants in 2002 and 2006-2007 as well as the National Security Education Program for the David L. Borden Fellowship in 2003 for funding my fieldwork in Zagreb. They are not responsible for this research or its representation. I thank Nataša Renko, the University of Zagreb Faculty of Economics and Business, Ante Tonči Vladislavić, and the Center for Women's Studies in Zagreb for their assistance with fieldwork and analysis. Finally, I thank the informants for generously participating in this research.

\section{ORCID}

Katherine C. Sredl http://orcid.org/0000-0001-7426-9836 


\section{References}

Aitken, Rob. 2003. "The democratic method of obtaining capital-culture, governmentality and the ethics of mass investment." Consumption Markets \& Culture 6 (4): 293-317.

Arnould, Eric, and Craig Thompson. 2005. "Consumer Culture Theory: Twenty Years of Research.” Journal of Consumer Research 31 (March): 868-882.

Askegaard, Soren, and Jeppe Trolle Linnet. 2011. "Towards an epistemology of consumer culture theory: Phenomenology and the context of context." Marketing Theory 11 (4): 381-404.

Barilar, Vesna, Željka Jelavić, and Sandra Prlenda. 2005. "Women in Croatia: continuity and change.” In Female Well-being: toward a global theory of social change.” Ed Janet Mancini Billson and Carolyn Fluehr-Lobban. New York: Zed Books, 159-180.

Barry, Andrew, Thomas Osbourne, and Nikolas Rose. 1996. Foucault and Political Reason: Liberalism, Neo-liberalism and Rationalities of Government. London: Routledge.

Belk, Russell W., Melanie Wallendorf, and John F. Sherry Jr. 1989. "The Sacred and the Profane in Consumer Behavior: Theodicy on the Odyssey." Journal of Consumer Research 16 (June): 1-38.

Berdahl, Daphne. 1999. Where the World Ended: Re-Unification and Identity in the German Borderland. Berkeley: University of California Press.

Borgerson, Janet. 2005. "Materiality, Agency, and the Constitution of Consuming Subjects: Insights for Consumer Research," in North American Advances in Consumer Resesrch, 
Vol 32, ed. Geeta Menon and Akshay R. Rao, Duluth, MN: Association for Consumer ResearchL 439-43.

Butler, Judith. 1993. Bodies that matter: On the discursive limits of "sex." New York:

Routledge.

CIA World Factbook. 2017. Croatia. https://www.cia.gov/library/publications/the-worldfactbook/geos/hr.html accessed June 21, 2017.

Croatian Bureau of Statistics. 2016. "Women and Men in Croatia, 2016." Zagreb: Croatian Bureau of Statistics (CROSTAT).

Croatian Bureau of Statistics. 2012. "Population by Age and Sex, by Settlements, 2011 Census: City of Zagreb." Census of Population, Households and Dwellings 2011. Zagreb: Croatian Bureau of Statistics (CROSTAT).

Daly, Kerry J. 1996. Families and Time. Thousand Oaks, CA: Sage.

Drakulić, Slavenka. 1992. How We Survived Communism and Even Laughed. New York: HarperPerennial.

Dunn, Elizabeth C. 2004. Privatizing Poland: Baby Food, Big Business, and the Remaking of Labor. Ithaca: Cornell University Press.

Dunn, Elizabeth C. 1999. "Slick Salesmen and Simple People: Negotiated Capitalism in a Privatized Polish Firm," in Uncertain Transition: Ethnographies of Transformation in the Former Socialist World (Katherine Verdery and Michael Burawoy, eds), pp. 125-150. Boulder: Rowman and Littlefield.

Einhorn, Barbara. 1993. Cinderella Goes to Market: Citizenship, Gender, and Women's Movements in East Central Europe. London: Verso. 
Epp, Amber M., and Linda L. Price. 2008. “Family Identity: A Framework of Identity Interplay in Consumption Practices." Journal of Consumer Research 35 (June): 50-70.

European Commission. 2012. The current situation of gender equality in Croatia - Country Profile Accessed 9 March 2016. http://ec.europa.eu/justice/genderequality/files/epo_campaign/country-profile_croatia_en.pdf

Foucault, Michel. 1991. "Governmentality.” In The Foucault Effect. Studies in Governmentality, edited by G. Burchell, C. Gordon, and P. Miller, 87-104. Chicago, IL: University of Chicago Press.

Giesler, Markus and Ela Veresiu. 2014. "Creating the Responsible Consumer: Moralistic Governance Regimes and Consumer Subjectivity.” Journal of Consumer Research 41 (October): 840-857.

Gill, Rosalind and Christina Scharff, Eds. 2011. New femininities: postfeminism, neoliberalism and subjectivity. Basingstoke, Palgrave.

Gopaldas, Ahir and Glenna DeRoy. 2015. “An Intersectional Approach to Diversity Research.” Consumption Markets \& Culture 18 (4): 333-364.

Halbwachs, Maurice. 1980. The collective memory, New York, Harper \& Row Colophon Books. Harrison III, Robert L., Ann Veeck, and James W. Gentry. 2011. “A Life Course Perspective of Family Meals Via the Life Grid Method.” Journal of Historical Research in Marketing 3 (2): $214-233$.

Harvey, David. 2005. A Brief History of Neoliberalism. Oxford: Oxford University Press. 
Higson, Andrew. 2014. "Nostalgia Is Not What It Used To Be: Heritage Films, Nostalgia Websites and Contemporary Consumers.” Consumption Markets \& Culture 17 (2): 120142.

Holt, Douglas B. 2002. "Why Do Brands Cause Trouble? A Dialectical Theory of Consumer Culture and Branding." Journal of Consumer Research 29 (June): 70-90.

Holt, Douglas B. and Craig J. Thompson. 2004. "Man-of-Action Heroes: The Pursuit of Heroic Masculinity in Everyday Consumption.” Journal of Consumer Research 31 (September): 425-440.

Ilišin, Vlasta. 2007. "Political Values and Attitudes." In Democratic Transition in Croatia: Value Transformation, Education \& Media, edited by Sabrina Ramet and Davorka Matić: 108136. College Station: Texas A\&M University Press.

Izberk-Bilgin, Elif. 2012. "Infidel Brands: Unveiling Alternative Meanings of Global Brands at the Nexus of Globalization, Consumer Culture, and Islamism.” Journal of Consumer Research 39 (December): 663-687.

Johnson, Guillaume D., Kevin D. Thomas, and Sonya A. Grier. 2017. "When the burger becomes halal: a critical discourse analysis of privilege and marketplace inclusion." Consumption Markets \& Culture Advance online publication. doi: https://doi.org/10.1080/10253866.2017.1323741

Karababa, Eminegül, and Güliz Ger. 2011. "Early Modern Ottoman Coffeehouse Culture and the Formation of the Consumer Subject." Journal of Consumer Research 37 (February): $737-60$. 
Koffman, Ofra and Rosalind Gill. 2013. "The revolution will be led by a 12-year-old girl': girl power and global biopolitics." Feminist Review 105 (1): 83-102.

Leinert Novosel, Smiljana. 1990. Žene-politička manjina: Perspektive sudjelovanja žena u javnom životu [Women-Political Minorities: Perspectives of Women's Participation in Public Life]. Zagreb: NIRO Radničke novine.

Luthar, Breda. 2006. "Remembering Socialism: On Desire, Consumption and Surveillance." Journal of Consumer Culture 6 (2): 229-259.

Luthar, Breda and Maruša Pušnik. 2010. Remembering Utopia: The Culture of Everyday Life in Socialist Yugoslavia. Washington, D.C.: New Academia Publishing.

Marjanović, Vuko, and Družijanić. 2009. "Pljačka Hrvatske ostat će nekažnjena, a 360.000 radnika bačeno je na ulicu [The Plunder of Croatia will remain unpunished, and 360,000 workers are thrown into the street]." Slobodna Dalmacija. September 30, 2009. http://www.slobodnadalmacija.hr/novosti/hrvatska/clanak/id/69544/pljacka-hrvatskeostat-ce-nekaznjena-a-360000-radnika-baceno-je-na-ulicu

McCracken, Grant. 1988. The Long Interview. Thousand Oaks, Sage.

McRobbie, Angela. 2009. The Aftermath of Feminism: gender, culture and social change. London, Sage.

Mikkonen, Ilona, and Bajde Domen. 2012. "Happy Festivus! Parody as Playful Consumer Resistance." Consumption Markets \& Culture 16 (4): 311-337.

Mikkonen, Ilona, Handan Vicdan, and Annu Muarkkula (2014), "What not to wear? Oppositional ideology, fashion, and governmentality in wardrobe self-help." Consumption Markets \& Culture 17 (3): 254-273. 
Mikkonen, Ilona, Johanna Moisander, and Fuat Firat. 2011. “Cynical Identity Project as Consumer Resistance: The Scrooge as a Social Critic.” Consumption Markets \& Culture 14 (1): 99-116.

Otnes, Cele C., Julie A. Ruth, Tina M. Lowrey, and Suraj Commuri. 2006. “Capturing Time.” In Handbook of Qualitative Research Methods in Marketing, edited by Russell W. Belk: 387-99. Edward Elgar: Cheltenham, UK.

Pavlovič, Tatjana. 1999. "Women in Croatia: Feminists, Nationalists, and Homosexuals," in Sabrina P. Ramet, ed. Gender and Politics in the Western Balkans, University Park, Pennsylvania: The Pennsylvania State University Press, 131-152.

Patterson, Patrick Hyder. 2011. Bought and Sold: Living and Losing the Good Life in Socialist Yugoslavia. Ithaca, NY: Cornell University Press.

Petričić, Darko. 2009. Hrvatska u mreži mafije, kriminala i korupcije [Croatia in a network of mafia, crime, and corruption]. Zagreb: Argus media.

Ringrose, Jessica and Valerie Walkerdine. 2008. "Regulating the Abject: The TV Make-Over as Site of Neoliberal Reinvention Toward Bourgeois Femininity.” Feminist Media Studies, 8 (3): $227-246$.

Rubić, Tihana (2013). “Afternoon Moonlighting - It Was a Must. The Dynamics and Paradoxes of the Croatian Socialist and Post-socialist Labor Market.” Nar. Umjet. 50/1: 121-145. Narodna umjetnost : hrvatski časopis za etnologiju i folkloristiku, Vol.50. No.1. Srpanj 2013. Folk art: Croatian Journal of Ethnology and Folklore Research, Vol.50. No.1. July 2013. 
Scharff, Christina. 2014. "Gender and Neoliberalism: Exploring the Exclusions and Contours of Neoliberal Subjectivities." Theory Culture \& Society, April 1, 2014, accessed June 1, 2016. https://www.theoryculturesociety.org/christina-scharff-on-gender-and$\underline{\text { neoliberalism/ }}$

Scharff, Christina. 2012. Repudiating feminism: young women in a neoliberal world. Burlington VT: Ashgate Publishing Company.

Spajić-Vrkaš, Vedrana. 2003. "Visions, Provisions and Reality: Political Changes and Education for Democratic Citizenship in Croatia.” Cambridge Journal of Education 33 (1): 33-51.

Sredl, Katherine C. 2005. “'Oh, you use 098, you must be from Hercegovina?' Communicating identity in everyday consumer rituals in Croatia," Anthropology of East Europe Review, 23, 2, 90-93.

Sredl, Katherine. 2007. “Consumption and Class during and after State Socialism.” In Research in Consumer Behavior, Vol. 11, Consumer Culture Theory, edited by Russell Belk and John Sherry, 187-205. Oxford: Elsevier.

Sredl, Katherine C. 2009. “Consumer Pride and Consumption-Based Family Rituals: A Field Study in Zagreb, Croatia.” PhD diss., University of Illinois at Urbana-Champaign.

Sredl, Katherine, and Nataša Renko. 2009. "Women’s Possessions and Social Class in Contemporary Zagreb.” Društvena istraživanja, Journal for General Social Issues (18) 3: $565-581$.

Strober, Myra H., and Charles B. Weinberg. 1980. "Strategies Used by Working and NonWorking Wives To Reduce Time Pressures." Journal of Consumer Research 6 (March): $338-48$. 
Švab, Alenka. 2002. "Consuming Western Image of Well-Being - Shopping Tourism in Socialist Slovenia." Cultural Studies 16 (1): 63-97.

Thompson, Craig J. 2014. "Politics of Consumer Identity Work.” Journal of Consumer Research 40 (February): iii-vii.

Thompson, Craig J., and Diana L. Haytko. 1997. “Speaking of Fashion: Consumers' Uses of Fashion Discourses and the Appropriation of Countervailing Cultural Meanings.” Journal of Consumer Research 24 (June): 15-42.

Thompson, Craig J., Howard R. Pollio, and William B. Locander. 1994. "The Spoken and the Unspoken: A Hermeneutic Approach to Understanding the Cultural Viewpoints That Underlie Consumers' Expressed Meanings.” Journal of Consumer Research 21 (December): 432-452.

Todorova, Maria and Zsuzsa Gille, eds. 2012. Post-communist Nostalgia. New York and Oxford: Berghahn Books.

Tumbat, Gülnur, and Russell W. Belk. 2011. "Marketplace Tensions in Extraordinary Experiences." Journal of Consumer Research 38 (June): 42-61.

Üstüner, Tuba, and Douglas B. Holt. 2010. “Toward a Theory of Status Consumption in Less Industrialized Countries.” Journal of Consumer Research 37 (June): 37-56.

Verdery, Katherine. 1996. What was socialism and what comes next? Princeton, NJ: Princeton University Press.

Zayer, Linda Tuncay, Katherine Sredl, Marie-Agnes Parmentier and Catherine Coleman. 2012. “Consumption and Gender Identity in Popular Media: Discourses of Domesticity, Sexuality and Authenticity." Consumption Markets \& Culture 15 (4): 333-357. 